\title{
Perbedaan Cybersex Pada Remaja Ditinjau Dari Usia Dan Jenis Kelamin Di Pekanbaru
}

\author{
Harmaini \\ harmaini@uin-suska.ac.id
}

Sri Ayu Novitriani

\author{
Fakultas Psikologi, Universitas Islam Negeri (UIN) Sultan Syarif Kasim Riau, \\ Indonesia.
}

\begin{abstract}
Adolescence is a transitional or transitional period in human development that connects childhood and adulthood. One of the transitions that occur is sexual development. Teenage sexual development which is turbulent and high curiosity about sexuality makes some teenagers choose cybersex to fulfill their sexual desires. Cybersex is a behavior carried out for sexual pleasure through media that has an internet connection stored in a gadget or computer, and teenagers easily see the desired sexuality content. This makes adolescents into free sex, sexually transmitted diseases, and pregnancies outside of marriage. This study aims to determine the differences in cybersex in adolescents in terms of age and sex. This research method uses descriptive quantitative. The subjects in this study were 400 adolescents aged 12-21 years using purposive sampling technique. The instrument used was the scale of the Cyber Pornography Use Inventory (CPUI) with a reliability coefficient of 0.930 . Based on the results of the study, there were differences in cybersex in adolescents in terms of age and sex, where cybersex at the end of adolescence was higher than the early adolescents and middle adolescents, and cybersex in men was higher than women.
\end{abstract}

Keywords: age; cybersex; gender; youth.

\begin{abstract}
Abstrak
Remaja adalah masa transisi atau peralihan dalam perkembangan manusia yang menghubungkan masa kanak-kanak dan masa dewasa. Salah satu peralihan yang terjadi adalah perkembangan seksual. Perkembangan seksual remaja yang sedang bergejolak dan rasa ingin tahu yang tinggi mengenai seksualitas menjadikan sebagian remaja memilih cybersex untuk memenuhi hasrat seksualitasnya. Cybersex merupakan perilaku yang dilakukan untuk kesenangan seksual melalui media yang memiliki koneksi internet yang tersimpan didalam gadget atau komputer, dan remaja dengan mudah melihat konten seksualitas yang diinginkan. Hal ini menjadikan remaja masuk kedalam perilaku seks bebas, penyakit menular seksual, dan kehamilan diluar nikah. Penelitian ini bertujuan untuk mengetahui perbedaan cybersex pada remaja ditinjau dari usia dan jenis kelamin. Metode penelitian ini menggunakan kuantitatif deskriptif. Subjek dalam penelitian ini berjumlah 400 remaja yang berusia 12-21 tahun dengan menggunakan teknik purposive sampling. Instrumen yang digunakan adalah skala Cyber Pornography Use Inventory (CPUI) dengan koefisien reliabilitas sebesar 0,930. Berdasarkan hasil penelitian menunjukan adanya perbedaan cybersex pada remaja ditinjau dari usia dan jenis kelamin, dimana cybersex pada usia remaja akhir lebih tinggi dibandingkan dengan usia remaja
\end{abstract}


awal dan usia remaja madya, serta cybersex pada laki-laki lebih tinggi dibandingkan dengan perempuan.

Kata Kunci: cybersex; jenis kelamin; remaja; usia.

Psikoislamika: Jurnal Psikologi dan Psikologi Islam (JPPI) Volume 16. Nomor 1. Tahun 2019. Copyright (C 2019. Pusat Penelitian dan Layanan Psikologi.

\section{PENDAHULUAN}

Salah satu produk teknologi informasi yang berkembang sangat pesat saat ini adalah internet yang memungkinkan masyarakat diseluruh belahan dunia dapat berkomunikasi dengan mudah tanpa harus bertemu secara fisik. Internet menghadirkan berbagai macam kemudahan baik bagi pengguna dalam berkomunikasi dengan pengguna lain, membangun jejaring sosial, mengedarkan atau mendapatkan informasi secara bebas, dan berbagai manfaat lainnya yang dapat dilakukan melalui internet.

Perkembangan internet yang sangat pesat dengan segala kelebihan dan manfaatnya ternyata juga menghadirkan masalah lain, salah satunya adalah fenomena cybersex. Cybersex adalah aktivitas-aktivitas yang mengandung unsur porno didalamnya, seperti melihat gambargambar erotis, terlibat dalam chatting tentang seks, saling tukar menukar gambar atau pesan email tentang seks (Cooper, 2002). Fenomena ini didukung hasil riset yang dilakukan terhadap 1.200 orang pelajar SMP dan SMA di 12 kota di Indonesia, 97\% pelajar pernah dan suka membuka situs porno (harmaini, 2014).

Fenomena cybersex ini memiliki dampak yang negatif bagi remaja. Ketua Komisi Fatwa MUI kota Pekanbaru menyebutkan bahwa tontonan televisi, video, bahkan internet memiliki pengaruh besar yang menyebabkan penyimpangan seksual kian menjadi-jadi saat ini. Belum lagi dengan mudahnya saat ini mendapatkan video porno, baik berupa CD maupun melihatnya di internet (http://riaupos.co). Salah satu kasus yang terjadi diungkapkan dalam Metro Riau (2013) bahwa di Pekanbaru seorang anak baru gede (ABG) yang berusia 15 tahun melakukan pencabulan terhadap bocah berusia 6 tahun di dalam rumahnya setelah menonton video porno di warung internet (Warnet).

Fenomena mengenai aktifitas cybersex di warung internet kota Pekanbaru ini juga dibenarkan oleh beberapa penjaga warnet dan pemilik warnet. Berdasarkan hasil wawancara yang peneliti lakukan di lima warnet yang berbeda di Pekanbaru, setiap harinya (24 jam) jumlah pengunjung warnet sebanyak 200-500 orang, dan terdiri dari anak-anak umur 5 tahun hingga 60 tahun. Fakta yang didapat berdasarkan wawancara yang telah peneliti lakukan, pengunjung yang didominasi oleh para remaja ini, selain bermain game online, setiap harinya pasti ada yang mengakses situs porno, baik itu melihat, mendownload, dan melakukan obrolan di sosial media (chatting) yang mengarah ke pornografi. Bahkan, beberapa kali terjadi sepasang remaja sedang melihat video porno dan mereka mesum di warnet. 
Prihartini, Nuryoto, dan Aviatin (2002) dalam penelitiannya mengatakan bahwasannya dorongan seksual yang meningkat dan rasa ingin tahu yang besar tentang seksualitas seringkali membawa remaja yang sedang berada dalam posisi rentan kepada kasus-kasus "keterlanjuran". Masalah-masalah "keterlanjuran" akibat seksualitas pada remaja dapat berupa kehamilan pranikah, perilaku seksual remaja yang semakin bebas, dan penularan penyakit seksual. Fenomena tersebut juga diperkuat oleh pemberitaan di media massa mengenai maraknya perilaku seksual bebas di kalangan remaja. Hal ini di dukung oleh penelitian Daneback, Cooper, dan Mansson (dalam Sari dan Purba, 2012) yang mengatakan bahwa yang paling banyak menggunakan internet untuk tujuan seksual adalah remaja.

Rasa ingin tahu yang besar mengenai seksualitas menyebabkan remaja mencari sumber informasi mengenai seksualitas. Penelitian Harmaini dan Mukhlis (2010) mencatat bahwa remaja di Pekanbaru mendapatkan informasi mengenai seksualitas terbanyak ke dua adalah melalui internet, lalu $\mathrm{dvd} / \mathrm{vcd}$, dan HP. Media merupakan sumber informasi yang mudah di akses dan didapatkan, namun tidak dapat dipertanggung jawabkan dampaknya karena remaja dapat salah memberikan arti terhadap apa yang dilihat, sehingga memunculkan dampak yang negatif.

Fenomena seksual yang pelakunya didominasi para remaja ini merupakan suatu masalah yang sangat serius. Kerentanan remaja dalam menghadapi masalah seksualitas timbul seiring dengan perkembangan remaja yang sedang dalam masa transisi. Masa transisi merupakan masa peralihan. Pada masa ini baik laki-laki ataupun perempuan mengalami perkembangann fisik dan psikis dengan ciri yang berbeda. Hurlock (1980) menyatakan awal perkembangan remaja terjadi pada periode pubertas. Pada periode ini terjadi perkembangan alat-alat dan hormon-hormon seksualitas yang akan mempengaruhi kondisi psikis remaja. Kematangan secara seksual membuat remaja menjadi mudah terangsang akan hal-hal yang berbau seksualitas karena dorongan seksual yang meningkat.

Bagi sebagian besar remaja, fenomena seks dunia maya ini dianggap masih sangat tabu dan merupakan perilaku seksual yang tidak lazim. Namun ada juga yang menganggap perilaku ini merupakan suatu cara yang paling aman untuk menyalurkan hasrat seksualnya terutama bagi mereka yang belum memiliki pasangan. Hal inilah yang kemudian memicu perbedaan sikap diantara kaum muda tersebut (Pribadi dan Putri, 2009).

Fakta menunjukan ternyata usia berkaitan dengan sikap positifnya remaja melakukan cybersex. Penelitian Pribadi dan Putri (2009) mengungkapkan data yang diperoleh berdasarkan deskripsi subjek yang di dasarkan pada usia menunjukan bahwa sikap terhadap seks dunia maya pada subjek yang berusia antara 21-24 tahun lebih tinggi dibanding subjek yang berusia 18-21 tahun atau 25-30 tahun. Rimington (2008) menyebutkan dalam penelitiannya bahwa usia 21-24 tahun telah masuk ke dalam kategori sexually compulsivity. Sexually compulsivity adalah perilaku seksual yang kompulsif, dimana perilaku seksual ini merupakan lanjutan dari 
cybersex yang berkonsekuensi terhadap kehidupan nyata (Delmonico, dalam Laws \& O'Donohue, 2008).

Menurut Cooper dan Scherer (dalam Andini, 2009), jenis kelamin laki-laki sangat menentukan pemilihan media yang digunakan di dalam internet. Hal ini disebabkan oleh adanya perbedaan secara biologis dan psikologis antara pria dan wanita. Bila dilihat dari faktor biologis perubahan hormonal pada pria yakni dengan meningkatnya hormon testosteron dapat membangkitkan minat yang tinggi terhadap hal yang berkaitan dengan seksual. Lebih lanjut dijelaskan oleh Dagun (1992) secara psikis pria umumnya lebih agresif,

\section{TINJAUAN PUSTAKA}

\section{Cybersex}

Cooper et all (2004) mendefenisikan cybersex sebagai sebuah bagian dari Online Sexual Activity (OSA) dan juga dapat didefenisikan sebagai individu yang menggunakan internet untuk mendapatkan hal-hal yang menarik dalam aktifitas seksual.

Hal serupa diungkapkan oleh Carners, Delmonico dan Griffin (2001) bahwa cybersex adalah mengakses pornografi di internet, terlibat dalam real-time yaitu percakapan tentang seksual online dengan orang lain, dan mengakses multimedia software.

Delmonico (dalam Laws \& O'Donohue, 2008) menyatakan bahwa ada 5 (lima) aspek dan ditambah lagi dengan 2 (dua) single item individu melakukan aktifitas cybersex, yaitu Online Sexual Compulsivity, Online Sexual Behavior Social, Online Sexual Behavior Isolation, Online Sexual Spending, dan Interest in Online sangat aktif, sangat berterus terang dan tidak malu untuk membicarakan masalah seks. Berbeda halnya dengan wanita yakni tidak agresif, pasif, merasa tidak bebas untuk membicarakan masalah seks.

Berdasarkan fenomena yang telah diuraikan maka peneliti tertarik untuk melakukan penelitian Perbedaan Cybersex pada Remaja ditinjau dari Usia dan Jenis Kelamin di Pekanbaru. Peneliti tertarik melakukan penelitian di Pekanbaru karena Pekanbaru memiliki gelar Pekanbaru Kota Madani, yang artinya kota yang berisikan masyarakat yang agamis dan berperadaban, berkualitas dan berkemajuan.

Sexual Behavior. Dua (dua) single item lainnya adalah non-home use of the internet dan Illegal online behavior.

Grubbs, Volk, dan Sessoms
(2014) memperbaharui dengan mengemukakan beberapa aspek penting yang ada pada cybersex, yang berdasarkan pada teori dari Delmonico diatas, yaitu 1. Tingkat kecanduan, dimana semakin seringnya individu melihat tontonan seksual atau pornografi di internet akan menambah tingkat kecanduannya pula. Semakin tinggi tingkat kecanduan menyebabkan semakin berkurangnya kemampuan untuk mengontrol diri menghindari pornografi, 2. Perasaan bersalah, yaitu munculnya perasaan bersalah ketika bersentuhan dengan pornografi dan seksualitas. Semakin tinggi perasaan bersalah yang dimiliki seorang individu mengindikasikan semakin tinggi pula tingkat kecanduan yang dimiliki, dan 3. Perilaku online seksual-sosial, perilaku kecanduan pornografi atau cybersex ini akan mempengaruhi kehidupan sosial 
individu, mereka akan lebih berfokus dan menghabiskan waktu untuk melihat tayangan pornografi yang dapat menimbulkan kesenangan bagi mereka, dan melupakan kegiatankegiatan yang seharusnya bersifat konstruktif dan positif.

\section{HIPOTESIS}

Terdapat perbedaan cybersex pada remaja ditinjau dari usia dan jenis kelamin di Pekanbaru.

\section{METODE PENELITIAN}

Subjek dalam penelitian ini adalah remaja berusia 12-21 tahun dan berdomisili di Pekanbaru, yang berjumlah 400 remaja. Metode pengumpulan data dengan menggunakan skala yaitu skala Cyber Pornography Use Inventory (CPUI) dari Grubbs dkk (2014). Skala Cyber Pornography Use Inventory (CPUI) ini merupakan alat ukur yang

Tabel 1. Data Responden Berdasarkan Kecamatan

\begin{tabular}{|c|c|c|c|c|c|c|c|c|}
\hline \multirow[t]{2}{*}{ No } & \multirow[t]{2}{*}{$\begin{array}{l}\text { Nama } \\
\text { Kecamatan }\end{array}$} & \multicolumn{2}{|c|}{$\begin{array}{l}\text { Remaja } \\
\text { Awal }\end{array}$} & \multicolumn{2}{|c|}{$\begin{array}{l}\text { Remaja } \\
\text { Tengah }\end{array}$} & \multicolumn{2}{|c|}{$\begin{array}{l}\text { Remaja } \\
\text { Akhir }\end{array}$} & \multirow[t]{2}{*}{ Total } \\
\hline & & $\mathrm{Lk}$ & $\mathrm{Pr}$ & Lk & $\operatorname{Pr}$ & Lk & $\operatorname{Pr}$ & \\
\hline 1 & Tampan & 5 & 5 & 5 & 5 & 5 & 6 & 31 \\
\hline 2 & Payung Sekaki & 5 & 5 & 5 & 5 & 5 & 6 & 31 \\
\hline 3 & Bukit Raya & 5 & 5 & 5 & 5 & 6 & 6 & 32 \\
\hline 4 & $\begin{array}{l}\text { Marpoyan } \\
\text { Damai }\end{array}$ & 6 & 6 & 6 & 6 & 6 & 6 & 36 \\
\hline 5 & Tenayan Raya & 5 & 5 & 5 & 5 & 5 & 5 & 30 \\
\hline 6 & Suka Jadi & 7 & 6 & 7 & 6 & 7 & 6 & 39 \\
\hline 7 & Lima Puluh & 5 & 5 & 5 & 5 & 5 & 5 & 30 \\
\hline 8 & Sail & 5 & 5 & 5 & 4 & 5 & 4 & 28 \\
\hline 9 & Pekanbaru Kota & 5 & 6 & 6 & 6 & 6 & 6 & 35 \\
\hline 10 & Senapelan & 6 & 6 & 6 & 7 & 6 & 6 & 37 \\
\hline 11 & Rumbai Pesisir & 6 & 5 & 6 & 6 & 5 & 6 & 34 \\
\hline 12 & Rumbai & 6 & 8 & 6 & 6 & 6 & 5 & 37 \\
\hline Tota & & 66 & 67 & 67 & 66 & 67 & 67 & 400 \\
\hline
\end{tabular}

memperbaharui ISST dari Delmonico (dalam Laws \& O'Donohue, 2008) yang memiliki tujuan yang sama yaitu mengungkap fenomena mengenai cybersex. CPUI ini berjumlah 32 item untuk pengumpulan data. Skala ini merupakan modifikasi dimana skala CPUI ini menggunakan bahasa Inggris dan telah diterjemahkan oleh peneliti sebelumnya, yaitu Rosdiana Arifani (2016). Peneliti melakukan modifikasi dengan mengubah, menambah, dan juga menghilangkan beberapa kata dalam item yang dianggap penting

Teknik analisis data yang digunakan dalam penelitian ini adalah Oneway Anova dengan alasan penelitian bersifat analisa komparasional yaitu untuk melihat perbedaan cybersex yang ditinjau dari usia dan Independent T-Test untuk melihat cybersex yang ditinjau dari jenis kelamin. 
Tabel 2. Gambaran Subjek Penelitian Berdasarkan Usia.

\begin{tabular}{|c|c|}
\hline Jumlah & Jenis Kelamin \\
\hline Remaja Awal 12-15 Tahun 133 & $\begin{array}{l}\text { Lk }: 66 \\
\operatorname{Pr}: 67\end{array}$ \\
\hline $\begin{array}{l}\text { Remaja madya } 15-18 \quad 133 \\
\text { Tahun }\end{array}$ & $\begin{array}{l}\text { Lk }: 67 \\
\operatorname{Pr}: 66\end{array}$ \\
\hline Remaja Akhir 18-21 Tahun 134 & $\begin{array}{l}\text { Lk }: 67 \\
\operatorname{Pr}: 67\end{array}$ \\
\hline Total & 400 \\
\hline 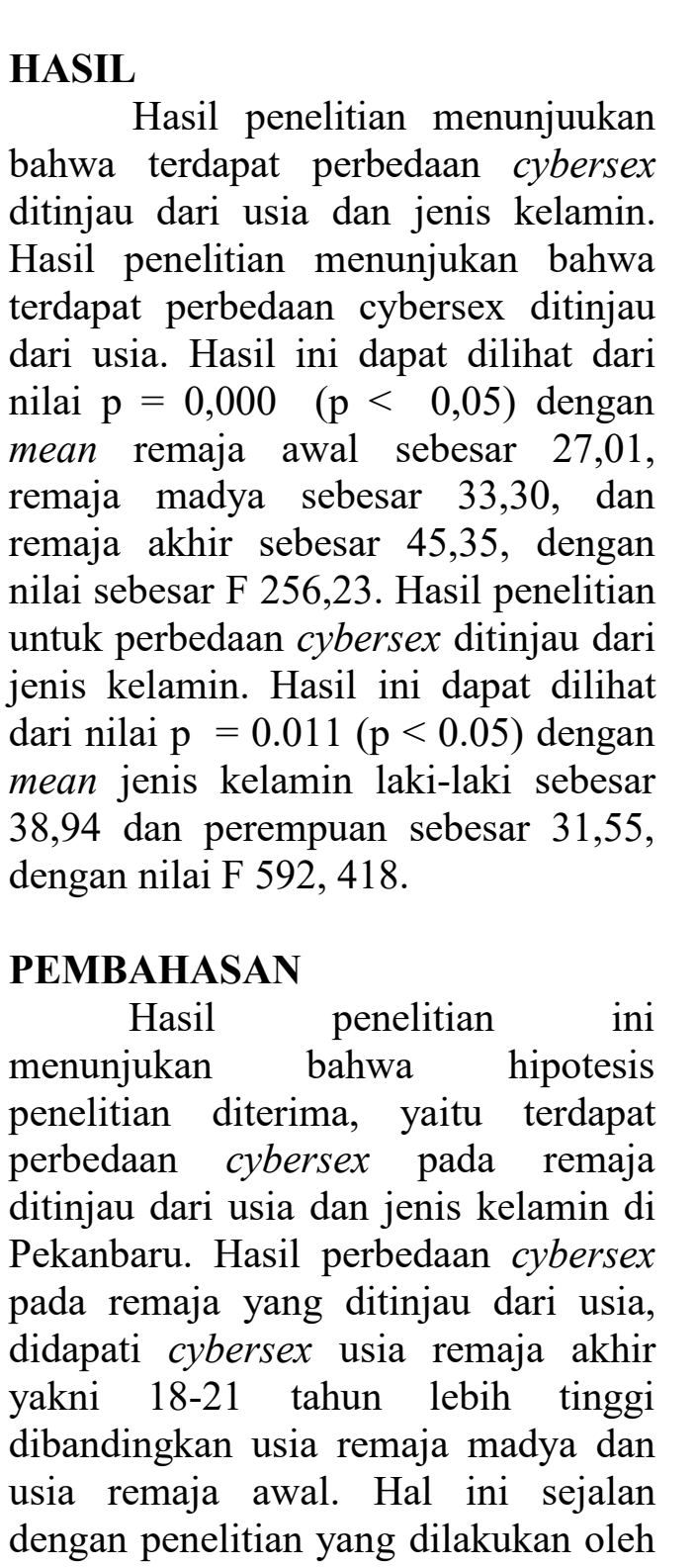 & $\begin{array}{l}\text { Aprilia, Maryanti, Safitri (2009) } \\
\text { dimana usia remaja akhir menunjukan } \\
\text { sikap positif lebih banyak terdapat } \\
\text { pada subjek usia } 20 \text { tahun. Pada hasil } \\
\text { penelitian menunjukkan dalam } \\
\text { pengukuran variabel cybersex terdapat } \\
\text { perbedaan antara remaja awal, remaja } \\
\text { madya, dan remaja akhir. Remaja } \\
\text { akhir lebih tinggi pada setiap aspek } \\
\text { dalam variabel cybersex, yang kedua } \\
\text { yaitu remaja madya, dan terakhir } \\
\text { remaja awal. Mardiati dkk (2013) } \\
\text { dalam penelitiannya mengatakan } \\
\text { bahwa para peneliti mengemukakan } \\
\text { otak manusia menjadi mulai matang } \\
\text { pada usia } 20 \text { tahunan, dimana perilaku } \\
\text { manusia sering menuju kepada } \\
\text { pencarian kesenangan, dan } \\
\text { kenyamanan. Perilaku ini dipandu oleh } \\
\text { hubungan antar sinaps melalui } \\
\text { neurotransmiter. Dopamin, merupakan } \\
\text { salah satu neurotransmiter membuat } \\
\text { rasa menyenangkan ran dan } \\
\text { menyamankan, keterpesonaan pada } \\
\text { berbagai hal. Rianto (2015) dalam } \\
\text { penelitiannya membuktikan bahwa } \\
\text { representasi seksualitas dalam dunia } \\
\text { cyber lebih dipahami sebagai sebuah } \\
\text { kesenangan dan komoditas, dimana } \\
\text { berbagai reportasi pelaku seksual } \\
\text { menggambarkan bagaimana } \\
\text { kesenangan akan hubungan seksual } \\
\text { yang sangat diinginkan oleh pelaku. }\end{array}$ \\
\hline
\end{tabular}


Piaget (dalam Santrock, 2001) mengatakan bahwa remaja termotivasi untuk memahami dunia karena perilaku adaptasi secara biologis mereka. Usia 12 tahun keatas masuk kedalam tahap operasional formal, dimana remaja sudah mampu menalar secara abstrak dalam situasi yang menawarkan beberapa kesempatan untuk melakukan penalaran hipotesis dan berpikir proposional. Artinya saat remaja dihadapkan pada suatu permasalahan maka remaja akan mencari jalan keluar dengan memprediksi apa yang mungkin akan terjadi jika suatu tindakan diambil. Hal inilah salah satu alasan mengapa remaja melakukan cybersex. Rasa ingin tahu yang besar dan gelora akan seksualitas menjadikan remaja mengakses konten seksual melalui internet dengan beberapa alasan diantaranya mudah diakses, biaya yang dikeluarkan sedikit, dan aman dari penyakit menular seksual (Sari \& Purba, 2012).

Keputusan mengenai cybersex yang pada akhirnya dilakukan oleh remaja akhir untuk memenuhi gelora akan seksualitasnya, secara perkembangan kognitif berlangsung pada korteks serebral. Solso, Maclin, dan Maclin (2007) menyebutkan bahwa korteks serebral berfungsi sebagai pusat proses berfikir dan kognisi (persepsi, memori, pemecahan masalah, dan proses bahasa). Korteks serebral memiliki bagian yang dinamakan lobus frontal, dimana pada bagian ini memiliki fungsi dalam pengendalian impuls, pertimbangan (judgment), pemecahan masalah, pengendalian dan pelaksanaan perilaku. Maka, ketika otak pada usia remaja akhir sudah mulai matang, ini menandakan bahwa fungsi pada korteks serebral semakin membaik. Pertimbangan inilah yang menjadikan remaja mengakses konten seksual melalui internet dengan beberapa alasan diantaranya, mudah diakses, biaya yang dikeluarkan sedikit, dan aman dari penyakit menular seksual (Sari dan Purba, 2012).

Penelitian ini juga menunjukan adanya perbedaan cybersex pada jenis kelamin laki-laki dan perempuan, dimana cybersex pada laki-laki lebih tinggi dibandingkan dengan perempuan. Perbedaan perilaku ini dapat dilihat dari sikap seksual yang dimiliki berbeda antara laki-laki dan perempuan.

Dagun (1992) mengemukakan alasan dimana perbedaan sikap seks dunia maya dipengaruhi oleh faktor biologis dan psikologis. Secara psikis, laki-laki umumnya lebih agresif, sangat aktif, sangat berterus terang dan tidak malu-malu untuk membicarakan masalah seks, berbanding terbalik dengan wanita yang tidak agresif, pasif, dan merasa tidak bebas untuk membicarakan seks. Brizendine (2014) juga menyebutkan bahwa $85 \%$ lakilaki pada usia 20-30 tahun memikirkan seks setiap 52 detik, sementara perempuan hanya sekali sehari atau sampai tiga atau empat kali ketika mereka sedang sangat subur.

Secara biologis baik pada lakilaki maupun perempuan, hormon testosteron adalah bahan bakar kimiawi yang menggerakkan mesin seksual di otak. Bila ada cukup bahan bakar, testosteron menggiatkan hipotalamus, menghidupkan bermacam perasaan erotis, dan membangkitkan fantasi seksual. Brizendine (2014) menambahkan perbedaannya terletak pada, laki-laki secara rata-rata memiliki sepuluh 
hingga seratus kali lebih banyak testosteron dibandingkan dengan perempuan. Maka terdapat perbedaan yang jelas dalam hal libido dan perilaku seksual. Pada usia 8-14 tahun, tingkat estrogen seorang gadis meningkat 10-20 kali, tetapi tingkat testosteronnya naik hanya sekitar lima kali. Bandingkan dengan testosteron seorang anak laki-laki yang meningkat 25 kali lipat pada usia 9-15 tahun. Dengan semua bahan bakar seksual tambahan itu, remaja laki-laki biasanya merasakan dorongan seks tiga kali lebih sering daripada remaja perempuan yang sebaya.

Berdasarkan uraian diatas, tidak jarang cybersex yang dilakukan remaja berlanjut pada seks secara real dengan pasangannya. Saputro (2015) dalam penelitiannya menyebutkan bahwa subjek telah menggunakan jasa cybersex dalam jenis percakapan seks online dan kemudian berlanjut ke hubungan seksual pranikah. Hal ini

DAFTAR PUSTAKA

Aprilia, Karina., Maryanti, Sulis dan Safitri. 2009. Sikap Mahasiswa Universitas Indonusa Esa Unggul terhadap Cybersex. Jurnal Psikologi. Vol. 7. No. 2. Desember.

Andini, Ida, A. P. S (2009). Sikap terhadap Perilaku Seks Maya berdasarkan Jenis Kelamin pada Dewasa Awal. Jurnal Psikologi Vol. 2, No. 2, Juni.

Baron \& Byrne. 2003. Psikologi Sosial. Edisi Kesepuluh. Jilid 2. Jakrta: Erlangga.

Brizendine, Louann. 2006. Female Brain. Mengungkap Misteri juga didukung penelitian dari Taufik dan Anganthi (2005) dimana seluruh subjek laki-laki mengaku melakukan hubungan seksual dengan menggunakan media pornografi, sedangkan pada perempuan sebesar $76 \%$ yang telah melakukan hubungan seksual dan menggunakan media pornografi

\section{KESIMPULAN}

Berdasarkan hasil penelitian ini dapat disimpulkan bahwa terdapat perbedaan cybersex pada remaja ditinjau dari usia dan jenis kelamin. Perbedaan cybersex berdasarkan usia menunjukan usia remaja akhir yakni 18-21 tahun lebih tinggi dalam cybersex dibandingkan usia remaja madya dan remaja awal. Selanjutnya, perbedaan cybersex ditinjau dari jenis kelamin dimana laki-laki lebih tinggi dalam cybersex dibandingkan perempuan.

Otak Perempuan. Jakarta: Phoenix Publishing Project.

Brizendine, Louann. 2010. Male Brain. Mengungkap Misteri Otak LakiLaki. Jakarta: Phoenix Publishing Project.

Carnes, Patrick., Delmonico, David. L., dan Griffin, Elizabeth. 2001. In the Shadow of the Net: Breaking Free of Compulsive Online Sexual Behavior. Center City, Minnesota: Hazelden.

Cooper, J. C. Delmonico, D., dan Burg. 2000. Cybersex User, Abusers, and Compulsive: New Findings and Implications. Journal Sexual 
Addiction \& Compulsivity, 7(1), 5- 29

Cooper, A. 2002. Sex and the Internet. U.S.A.: Brunner-Routledge.

Cooper, AL., Delmonico, D.L., Griffin-Shelley, dan E., Mathy, R.M. 2004. Online Sexual Activity: An Examination of Potentially Problematic Behaviors. Sexual Addiction and Compulsivity, 11, 129-143.

Dagun, Save M. 1992. Maskulin dan Feminim: Perbedaan Pria dalam Fisiologi, Psikologi, Seksual, Karier, dan Masa Depan. Jakarta: Rineka Cipta

Fenomena cybersex di http://riaupos .co/1951-spesialfenomena-dek adensi-moraldan-akhlak.html diakses pada hari jum'at, 06 Januari pukul 15.00 WIB.

Grubbs, Joshua. B., Volk, Fred., dan Sessoms, John. 2010. The Cyber-Pornography Use Inventory: The Development of a New Assesment Instrument. Sexual Addiction \& Compulsivity. The Journal of Treatment \& Prevention. Virginia: Routledge. 17. 106126.

Hurlock, Elizabeth B. 1980. Psikologi Perkembangan: Suatu Pendekatan Sepanjang Rentang Kehidupan. Edisi kelima. Jakarta: Erlangga.

Laws, D.R. \& O'Donohue, W.T. 2008. Sexual Deviance: Theory, assessment, and Treatment. New York: Guilford Press

Mardiati, Ratna. 2013. Modul Pelatihan Layanan Kesehatan Seksual Dan Reproduksi Ramah Remaja Untuk Dokter Praktik Swasta Di Daerah Yogyakarta. Yogyakarta: Kemitraan UNFPA dan Angsamerah Institution.

Mukhlis dan Harmaini. 2010. Perilaku Seksual Pranikah pada Remaja di Kota Pekanbaru. Jurnal Psikologi. Vol. 6, No. 2.

Pribadi, S. Adjie dan Putri, D. Eka (2009). Perbedaan Sikap terhadap Seks Dunia Maya Pada Mahasiswa ditinjau dari Jenis Kelamin. Jurnal Ilmiah Psikologi Universitas Gunadarma, Vol. 3. Oktober 2009.

Prihartini, Nuryoto, Aviatin. 2002. Hubunggan antara Komunikasi Efektif tentang Seksualitas dalam Keluarga dengan Sikap Remaja Awal terhadap Pergaulan Bebas antar Lawan Jenis. Jurnal Psikologi, No. 2, 124-139.

Rianto. 2015. Seksualitas Cyber: Sex Sebagai Kesenangan dan Komoditas. Jurnal Program Studi Komunikasi Universitas Islam Indonesia, Yogyakarta. Vol. 45, No. 2.

Rimington, Dolores. D. 2008. Examining the Perceived Benefits for Engageig in Cybersex Behaviour among College Student. Logan, Utah: 
Utah State University; MerrillCazier Library.

Sari, N. Novika dan Purba, R. Meilona. 2012. Gambaran Perilaku Cybersex pada Remaja Pelaku Cybersex di Kota Medan. Jurnal Psikologia-Online, Vol. 7. No. 2, hal. 62-73.

Santrock, J. W. 2001. Adolescence: Perkembangan Remaja. Edisi ke- 6. Jakarta: Erlangga
Saputro, Adi. 2015. Perilaku Seks Pranikah Mahasiswa Pengguna Jasa Cybersex di Kota Semarang. Undergraduate Thesis, Diponegoro University

Taufik dan Anganthi, N.R.N. 2005. Seksual Remaja: Perbedaan Seksualitas antara Remaja yang tidak Melakukan Hubungan Seksual. Jurnal Penelitian Humaiora. Vol. 6, No. 2. 